\title{
Formarea şi structura microflorei intestinale
}

\begin{tabular}{l} 
Sorin Buzinschi \\
Facultatea de Medicină, Universitatea Transilvania, Braşov, România \\
\hline
\end{tabular}

\begin{abstract}
REZUMAT
Populaţia bacteriană a tractului digestiv matur este cuprinsă în principal în 2 încrengături: Bacteriodetes şi Firmicutes. Formarea microbiotei intestinale parcurge o evoluţie stadială. Colonizarea bacteriană se consideră recent că începe in utero. Prezenţa bacteriilor în ţesutul placentar, în membranele fetale, lichidul amniotic şi în sângele cordonului ombilical la feţi şi nou-născuţi sănătoşi sugerează contactul precoce cu lumea bacteriană ca prim pas de instrucţie imunologică. Colonizarea tractului digestiv este continuată şi amplificată după naştere. Naşterea pe cale vaginală induce o populare intestinală care reflectă structura florei vaginale materne. Microbiota intestinală a născuţilor prin cezariană este dominată de flora cutanata şi orală maternă, însă cuprinde şi ecosistemul cutanat al personalului medical şi germeni provenind de pe suprafeţe. Laptele matern conţine bacterii vii provenind din ductele mamare, areolă, dar mai ales din intestinul matern, acesta fiind o sursă de colonizare naturală a intestinului neonatal. Popularea bacterienă fiziologică a intestinului modulează expresia genelor epiteliului pentru toleranţă imunologică, furnizează nutrimente gazdei şi contribuie la maturarea imunităţii sistemice.
\end{abstract}

Corpul uman şi patrimoniul sau microbian sunt componente ale unui imens ecosistem în care populația bacteriană conține de 100 ori mai multe gene şi de 10 ori mai multe celule decât cele umane $(1,2)$. Bacteriile sunt organisme monocelulare procariote la care materialul genetic nu este protejat de o membrană nucleară. Față de eucariote, ele se diferențiază prin prin prezența următoarelor componente: perete celular şi membrană plasmatică, citoplasmă în stare coloidală, ribozomi (sinteză proteică), informație genetică într-un cromozom circular (nucleozom) şi plasmide (conţin ADN dublu catenar), multiplicare de obicei prin diviziune directă. Din punct de vedere taxonomic se diferențiază prin marile domenii, încrengături (phylum), clase, ordine, familii, genuri, specii şi subspecii (2). În practică această ierarhie taxonomică nu este funcțională. În textele ştiinţifice vom găşi mai degrabă referiri la specii sau subspecii bacteriene, fiind evitată derularea unui lung lanț de ranguri taxonomice. Cel puțin pentru tractul digestiv sunt importante 2 încrengături: Bacteroidetes şi Firmicutes. Acestea constituie flora dominantă în populațiile de tip vestic; alte încrengături dețin in jur de $10 \%$ din microbiom (Proteobacteria - 4,5\%), in proporții mici ge- nul Escherichia, Helicobacter şi Actinobacter (3). Colonizarea microbiană normală a corpului uman este dependentă de condițiile mediului chimic local, de gradul de oxigenare, de aportul nutritiv al țesutului gazdă şi de intervenția sistemului imun. Unele specii proliferează folosind condițiile de nutriţie locală, aderă in nişele diferitelor organe şi prin succesiunea lor constituie baza unor populații stabile. În totalitate, microorganismele care colonizează suprafețele şi unele cavități ale organismului formează microbiota indigenă. Formarea microbiotei intestinale parcurge o evoluție stadială. Putem descrie o etapă prenatală, perioada alimentației exclusive la san sau prin formule de lapte, modificările microflorei după introducerea alimentației solide şi formarea microbiotei stabile.

\section{Colonizarea bacteriană in utero}

Conform opiniilor acceptate, mediul amniotic este considerat steril în cazul sarcinilor normale, la termen. În lumea animală însă, transmiterea microbiomului matern la făt este considerată un fenomen comun. Transmiterea verticală a microbiomului matern uman în placentă şi în meconiul fetal sugerează că procesul de colonizare începe înaintea naş- 
terii. Odată cu dezvoltarea neurologică fătul înghite lichid amniotic, în special în al 3-lea trimestru de sarcina, ceea ce constituie începutul colonizării. Prezența bacteriilor în țesutul placentar, în membranele fetale, în lichidul amniotic şi în sângele cordonului ombilical la feți şi nou-născuți sănătoşi, fără semne de infecție sau inflamaţie, sugerează contactul precoce cu lumea bacteriană ca prim pas de instrucție imunologică $(4,5)$. Flora microbiană din 320 specimene placentare recoltate steril a fost investigată prin secvențierea genetică 16SrRNA în corelație cu investigații similare ale microflorei gravidelor din cavitatea orală, piele, căi respiratorii (nazal), vaginală, şi ale microbiomului intestinal de către Aagard et al. (4). Autorul specifică biomasa scăzută a microbiomului placentar $(0,002 \mathrm{mg}$ ADN bacterian extras la $1 \mathrm{~g}$ tesut placentar). Profilul nişei microbiomului placentar studiat a cuprins genul Firmicutes, Tenericutes, Proteobacteria, Bacteriodetes şi Fusobacterii, tulpini comensale nepatogene $(4,5)$. Paradigmele curente consideră că majoritatea infecțiilor intrauterine soldate cu naşteri premature îşi au originea în tractul genital inferior prin ascensionarea germenilor în mediul steril intrauterin. $\mathrm{Cu}$ toate acestea numeroase clase bacteriene detectate local nu au provenit din tractul urogenital, ci au reprezentat specii comensale din cavitatea orală a gravidei (4). Unii dintre aceşti germeni ca Fusobacterium nucleatum (oral anaerob Gram -) transmis hematogen, funcționează ca un deschizător de drum pentru alţi comensali comuni ca tulpini de $E$ coli. Dintre speciile bacteriene identificate în placentă, E coli a fost, surprinzător, printre tulpinile cele mai abundente. Într-o trecere în revistă a datelor care arată transmiterea materno-fetală a comunităților bacteriene, Keeler şi Weilkamp (6) au evidențiat colonizarea bacteriană comensală a meconiului la 2 ore după naştere chiar înainte de alimentaţie şi prezența populației microbiene în segmentele de intestin rezecat imediat după naştere în cazul unor malformații. Bacteriile comensale din lichidul amniotic înghițit contribuie la maturarea intestinului fetal, la dezvoltarea sistemului imun şi la protecția prin competiție față de potenţialii patogeni.

Popularea bacteriană uterină în condiții fiziologice înafara sarcinii poate fi împărțită între germeni rezidenți, „turişti“ “ şi invadatori. Unele date infirmă existența unei populații stabile uterine care ar avea rol în menținerea homeostaziei locale (12). În cursul sarcinii, în opoziție cu paradigma mediului uterin steril, tehnicile de identificare moleculară a comunităților bacteriene au evidențiat achiziția unui microbiom care, aşa cum s-a arătat, contribuie la stabilirea unor relații imune, structurale şi metabolice cu gazda. Unele opinii consideră ipoteza colonizării intrauterine insuficient fondată prin limitarea metodelor moleculare la studiul biomasei minimale, lipsa unui control adecvat al contaminării şi incapacităţii de a dovedi viabiliatea bacteriană.

Prezența abundentă a bacteriilor în lichidul amniotic provoacă corioamniotita, creşterea locală a leucocitelor, a citochinelor proinflamatorii, fiind identificată ca o cauză pentru naşterea prematură (7). Bacteriile care produc infecții vaginale, urinare sau ale lichidului amniotic declanşează producția peptidelor antimicrobiene şi a citochinelor care sunt implicate în naşterea prematură şi/sau ruperea precoce a membranelor. $\mathrm{Cu}$ toate că infecțiile sunt factorii declanşatori importanți, modificarea cascadei inflamatorii prin polimorfisme ale genelor TLR4, IL-1 $\beta$, IL-4, IL-10, IL-1ra, TNF- $\alpha$ poate fi considerată una dintre premisele genetice ale naşterii premature (8). Creşterea severității prematurității se corelează cu nivelul ridicat al citochinelor proinflamatorii în lichidul amniotic, cu dezvoltarea abundentă a microbiotei în meconium şi cu structura comunității microbiene (9). Tulpinile de Enterobacter, Enterococcus şi Lactobacillus sunt corelate negativ cu vârsta gestațională din cauza răspunsului inflamator pe care îl declanşează (9).

Metodele tradiționale de identificare a germenilor prin culturi oferă date incomplete asupra populațiilor bacteriene ale microbiomului uman. Tehnicile metagenomice şi tehnologia de secvenţiere a revoluționat înțelegerea noastră asupra populațiilor microbiene. Secvențierea unei gene ribozomale (16SrRNA) specific conservată la procariote (bacterii) permite diferențierea între specii şi identificarea unora care nu au putut fi cultivate. Deşi paradigmele curente consideră că infecțiile intrauterine care provoacă naşteri premature sunt datorate germenilor din tractul genital inferior, în baza noilor tehnologii agenții cel mai frecvent identificați sunt comensali din cavitatea orală (Fusobacterium nucleatum, Gram -, anaerob şi alţii), transmişi pe cale hematogenă.

Sistemului imunitar îi revine rolul de a controla dezvoltarea microbiotei în perioada perinatală pentru ducerea la termen a sarcinii şi pentru controlul antigenilor în vederea constituirii stării de imunotoleranță.

\section{Microbiomul intestinal neonatal}

Colonizarea tractului digestiv inițiată din viața intrauterină este continuată şi amplificată cu rapidi- 
tate după naştere. Numeroşi factori determină compoziția microbiotei în primele etape de viață: tipul de naştere (vaginală/cezariană), alimentația naturală/artificială, mediul, igiena şi utilizarea de antibiotice. Microbiota vaginală suferă modificări importante în cursul sarcinei. Deşi compoziția tulpinilor bacteriene izolate diferă în unele studii, microbiomul vaginal apare a fi dominat de specii ca Lactobacillus, Clostridium şi Actinomicetes $(4,5,10)$. Între acestea, tulpinile de Lactobacillus prin producția de acid lactic scad pH-ul local (sub 4,5) cu efect protector față de colonizarea cu alte specii, în special patogene (10). Reducerea diversității microbiene intestinale a gravidei în trimestrul 3 de sarcină comparativ cu primul sugerează modificări similare cu cele din sindromul metabolic în care obezitatea şi rezistența la insulină au fost corelate cu structura microbiotei intestinale (11). În opoziţie cu efectele negative ale obezității, creşterea adipozitatii şi scăderea sensibilității la insulină sunt benefice în sarcină deoarece furnizează mai multă glucoză pentru făt şi pregătesc corpul pentru solicitările energetice ale lactației (11). Naşterea pe cale vaginală induce o colonizare intestinală care reflectă structura florei vaginale materne, dominată de specii de Lactobacillus şi Prevotella primele deținând $50 \%$ din întregul ecosistem bacterian (12). Alături de flora vaginală, flora fecală maternă contribuie la diversitatea colonizării cu Lactobacillus, Bifidobacterium, E coli şi Enterococcus. În prima săptămână de viață, microbiomul nou-născutului la termen este colonizat rapid cu specii din încrengătura Actinobacteria (incluzând Bifidobacterium), Proteobacteria, Bacteroidetes şi mai puțin Firmicutes $(4,13)$. In cazul naşterilor premature sub $1.200 \mathrm{~g}$ microbiomul intestinal este dominat de genul Firmicutes şi Tenericutes şi mai puţin de Actinobacteria $(4,5)$.

Ecologia intestinală la prematuri se caracterizează prin densitatea mică a germenilor şi a diversității în funcție de tipul naşterii, spitalizare şi modul de alimentaţie. Acest aspect nu este lipsit de importanță deoarece colonizarea primară a intestinului este prima lecție de imunitate a copilului. Colonizarea cu germeni materni permite o comunicare cu aceştia, exprimarea unor gene în epiteliul intestinal şi iniţierea circuitelor imune. Spre deosebire de naşterile pe cale vaginală, microbiota intestinală a născuților prin intervenție cezariană este dominată de flora cutanată şi orală maternă prin Propionilbacterium, Corynebacterium şi Streptococcus (10), cu o colonizare scăzută cu anaerobi că Bacteroides şi Bifidobacterium (13). În microbiomul acestora se mai reflectă şi ecosistemul cutanat al personalului medical, colonizarea microbiană a suprafețelor etc ceeace generează riscul popularii intestinale cu germeni rezistenți la antibiotice. În populația lor intestinală s-a identificat o proporție ridicată de gene bacteriene de rezistență la antibiotice. Tulpinile meticilino-rezistente de Staphylococcus aureus [MRSA] (prezent la 64-82\% dintre aceştia) ar explică prezența infecțiilor cutanate cu acest germene (10). Tratamentul cu antibiotice înainte sau în cursul naşterii modulează ecosistemul intestinal neonatal prin modificarea raportului dintre germenii Gram + şi cei Gram - şi posibil prin inducția rezistenței bacteriene la antibiotice. Polimorfismul colonizării intestinale poate explica diferențele mari între studiile publicate privind structura, ponderea şi evoluţia microbiotei neonatale. Primele bacterii colonizatoare structurează expresia genelor în celulele epiteliului intestinal creându-şi un habitat favorabil în detrimentul următorilor locuitori (13). Este important de subliniat că flora constituită la naştere influențează diversitatea şi funcționarea microbiomului intestinal luni, ani după naştere sau chiar compoziția florei la adulți.

\section{Alimentaţia naturală şi colonizarea intestinală}

Laptele uman asigură dezvoltarea optimă şi sănătoasă a copilului. În afara de principiile alimentare care asigură nutriţia sugarului în laptele matern se găsesc numeroase tipuri de oligozaharide, neutrofile, macrofage, celule $\mathrm{T}$ şi $\mathrm{B}$ dar şi bacterii vii. Unele dintre acestea provin din ductele mamare sau areolă, dar altele sunt componente intrinseci ale laptelui şi provin din microbiomul intestinal matern (14-16). Observațiile că laptele matern nu este steril, chiar colectat aseptic, sprijină idea că acesta este o sursă de colonizare bacteriană naturală a intestinului neonatal prin faptul că fragmente identice de ADN bacterian pot fi identificate în fecalele materne, sânge, lapte ca şi în scaunele sugarilor (15). În cazul alimentaţiei naturale transferul bacterian prin lapte reprezintă o modalitate de colonizare a intestinului neonatal cu o floră asemănătoare cu cea maternă realizându-se circulaţia germenilor prin circuitul entero-mamar-enteral.

Transferul bacteriilor viabile sau materialul genetic al acestora este asigurat de celulele mononucleare materne atât în cursul sarcinii, cât şi după naştere $(6,14)$. Greutatea maternă influențează microbiota intestinală şi compoziția florei transferate prin lapte (10). La femeile obeze gravide s-a constatat abundența tulpinilor de $S$. aureus în primele 6 luni de lactatie şi a celor de Lactobacillus în prima lună (10). Microbiomul matern este influențat de 


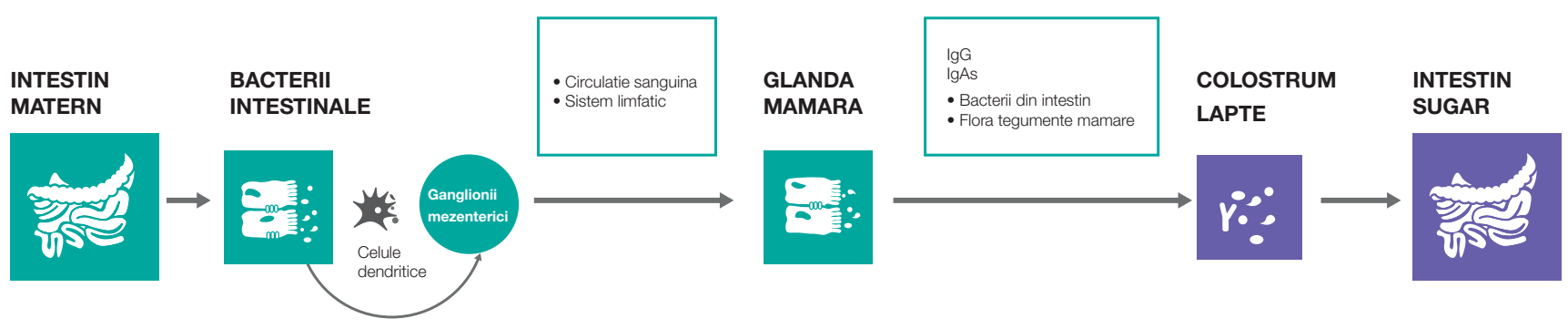

FIGURA 1. Transferul de informație imună de la intestinul matern la intestinul sugarului hrănit natural

factori genetici, imunologici, dietă şi medicaţie, elemente care îi determină structura florei intestinale şi configurația germenilor transferați la copil (6). Colonizarea intestinală a nou-născutului şi sugarului mai este dependentă de tegumentele sânului (pentru Staphylococcus, Corynebacteria şi alte bacterii cutanate ca Propionilbacteria), cavitatea orală maternă (Fusobacterium nucleatum, Bregeyella spp, Porphyromonas gingivalis etc) (17). Într-un studiu pe 1.032 de sugari în vârstă de 1 lună Penders et al (18) au constatat că născuții prin cezariană au o microfloră intestinală săracă în Bifidobacteria şi Bacteroides, fiind mai frecvent colonizați cu $\mathrm{Cl}$ difficile față de cei născuți pe cale vaginală. Sugarii alimentați exclusiv cu formule de lapte sunt mai frecvent colonizați cu $\mathrm{E}$ coli, $\mathrm{Cl}$ difficile, Bacteroides şi Lactobacillus. Spitalizarea şi prematuritatea cresc colonizarea tulpinilor de $\mathrm{Cl}$ difficile pe când tratamentul cu antibiotice scade populația de Bifidobacteria şi Bacteroides (18). Diferenţele dintre sugarii alimentaţi la sân şi cei hră- niţi cu formule de lapte nu se rezumă la compoziţia florei intestinale dar şi la efectele protectoare pe care le exercită Tabelul 1.

TABELUL 1. Diferențe între colonizarea intestinală a sugarilor alimentați natural vs. artificial şi protecția imună oferită $(13,18,19)$

\begin{tabular}{|l|l|}
\hline Sugari alimentați natural & Sugari alimentați artificial \\
\hline $\begin{array}{l}\text { Tractul diges v este colonizat } \\
\text { primar de Bifidobacteria, } \\
\text { Bacteroides }\end{array}$ & $\begin{array}{l}\text { Tractul diges v este colonizat } \\
\text { cu o floră diversă care conţine } \\
\text { E coli, Cl difficile, Bacteriodes, } \\
\text { Prevotella şi Lactobacillus }\end{array}$ \\
\hline $\begin{array}{l}\text { Laptele uman conţine } \\
\text { numeroşi factori an microbieni } \\
\text { şi imunomodulatori care } \\
\text { limitează creşterea patogenilor, } \\
\text { celule vii (neutrofile, } \\
\text { macrofage, limfocite T şi B) }\end{array}$ & $\begin{array}{l}\text { Flora microbiană complexă; } \\
\text { în proporţie ridicată anaerobi } \\
\text { faculta v/obligatoriu ca } \\
\text { şi Cl difficile }\end{array}$ \\
\hline
\end{tabular}

Colonizarea intestinală cu microbiota maternă este optimă în naşterea pe cale vaginală, la domiciliu şi în condițiile alimentației naturale. În maternităţi şi mai ales în spitale există şanse pentru coloni-

TABELUL 2. Microbiota intestinală la sugar şi relația comensală sau simbiotică cu gazda sa. Trecere în revistă a speciilor considerate semnificative $(10,13,19,20,21)$.

\begin{tabular}{|c|c|}
\hline Specii din flora intestinală & Colonizare \\
\hline Bifidobacterii & $\begin{array}{l}\text { Colonizează abundent tractul diges } v \text { al sugarilor mai ales prin } B \text { bifidus, } B \text { breve, } B \text { infan } \text { s. Sunt germeni } \\
\text { Gram + anaerobi; se localizează în strânsă legatură cu stratul mucos al epitelului. }\end{array}$ \\
\hline Lactobacillus & $\begin{array}{l}\text { Germeni Gram + colonizează mai ales colonul. În intes nul nou-născuţilor provin din flora vaginală maternă } \\
\text { şi din laptele matern. L acidophilus, cea mai comună specie de Lactobacillus, urmează bifidobacteriilor ca } \\
\text { importanţă în intes nul sugarilor alimentaţi natural. Adeziunea la epiteliul intes nal îi conferă proprietăţi } \\
\text { protectoare faţă de colonizarea cu patogeni. }\end{array}$ \\
\hline Clostridium & $\begin{array}{l}\text { Germeni Gram +, obligatoriu anaerobi, formatori de spori. Colonizează fiziologic tractul intes nal însă au } \\
\text { capacitatea de a elabora exotoxine (A şi B) fiind patogeni prin acestea şi potenţial patogeni prin formarea } \\
\text { de spori. Dintre speciile de Clostridium, Cl difficile colonizează intes nul sugarului fără a produce efecte } \\
\text { nocive în condiţii normale. Majoritatea sugarilor colonizaţi cu Cl difficile sunt asimptoma ci şi prezintă } \\
\text { an corpi de p lgG faţă de toxina A şi B care le conferă o imunitate de lungă durata. }\end{array}$ \\
\hline Bacteroides & $\begin{array}{l}\text { Germeni Gram -, obligatoriu anaerobi, comensali şi condiţionat patogeni, deţin 30\% din masa bacteriană } \\
\text { a intes nului. Prezintă relaţii mutuale cu gazda prin descompunerea substraturilor vegetale. Se dezvoltă } \\
\text { abundent în tractul diges v uman; consumul ridicat de proteine şi grăsimi animale îi favorizează colonizarea } \\
\text { pe când consumul predominent de carbohidraţi favorizează dezvoltarea speciilor de Prevotella. Bacteroides } \\
\text { fragilis, anaerob, în general comensal, face parte din flora colonică. Excretat în proporţie de } 0,5 \% \text { din } \\
\text { bacteriile prezente în scaun. Implicat în infecţiile cu anaerobi proveniţi din flora intes nală. }\end{array}$ \\
\hline Escherichia coli & $\begin{array}{l}\text { Germene Gram - faculta v anaerob, colonizează precoce intes nul sugarului. Laptele matern are efect } \\
\text { protector faţă de acesta prin inhibiţia colonizării. Unele specii sunt comensale, par cipă la sinteza vitaminei } \\
\text { K şi B, s mulează limfocitele să secrete IgA. Tulpini ca } \mathrm{O} 157: \mathrm{H7} \text {, secretoare de verotoxina pot produce } \\
\text { efecte severe ca enterită hemoragică şi sindrom hemoli c uremic. }\end{array}$ \\
\hline
\end{tabular}


zarea diversă, cu influențe pe termen lung asupra microbiomului nou-născutului şi sugarului. Odată cu diversificarea şi introducerea alimentelor solide se produc schimbari în compoziția microbiotei intestinale prin dezvoltarea unor specii prevalente la adulți (Bacteroidetes, Firmicutes şi Clostridium) (10). Modificările florei depind de evoluția substratului nutriţional, sursă pentru speciile comensale care extrag energie, produc vitamine, acizi graşi cu catenă scurtă şi aminoacizi.
Odată format, microbiomul intestinal stabileşte relații simbiotice cu gazda sa prin prelucrarea substraturilor nedigerate, limitarea nutrimentelor pentru patogeni şi competiție de spațiu cu aceştia, formarea stării de toleranță imună între bacterii şi sistemul imun, instrucţia şi dezvoltarea imunităţii sistemice. Tulburările de formare şi menţinere a microbiotei intestinale pot constitui factori de risc pentru patologia inflamatorie şi metabolică a adultului. 